\title{
Some Researches about the Soils Quality in the Aries Lower Corridor
}

\author{
Alin LUCACI ${ }^{1}$, Ion PĂCURAR ${ }^{1 *}$, Horea CACOVEAN ${ }^{2}$ \\ ${ }^{1}$ Faculty of Agriculture, University of Agricultural Sciences and Veterinary Medicine of Cluj Napoca, 3-5, \\ Mănăștur Street, Cluj Napoca, Romania; \\ ${ }^{2}$ Office of Soil and Agrochemical Studies Cluj, Fagului 1, Cluj-Napoca, Romania \\ *Corresponding author: ioan.pacurar@usamvcluj.ro \\ Bulletin USAMV series Agriculture 72(2)/2015 \\ Print ISSN 1843-5246; Electronic ISSN 1843-5386 \\ DOI 10.15835/buasvmcn-agr: 11742
}

\begin{abstract}
The studied area is presented as a depression called Aries Lower Valley, represented a contact unit, located between the Transylvanian Plain and Plateau Măhăceni, being a part of a wider close to the mountains area called Alba Iulia Aiud- Turda Valley. Taking place on approximately $50 \mathrm{~km}$ long, at the exit of the Aries River at Moldovenești-Buru Gorges, east of Trascău Mountains, with a width of 9-10 km, this territory is bounded on the west by the Mesozoic magmatic rocks of Piatra Secuiului area (Pop, 2001) and limestone strip of Trascău Mountains. The Aries Lower Valley represents a complex geographical unit located in a geomorphological contact area, with own geographical traits, were local natural factors influenced the suitability for the different forms of land-use. The orographic features resulting from the combination of elements like climate, hydrology, vegetation and soils cover gave a kind of coherence and unity for this geographical region.
\end{abstract}

Keywords: soil, contact unit, features, clime, hydrology, vegetation.

\section{INTRODUCTION}

Soil quality is an account of the soil's ability to provide ecosystem and social services through its capacities to perform its functions under changing conditions. The concept of soil quality expressed by this definition allows practical applications with regards to targeted social and/or ecosystem services. The concept of soil quality recognizes that the comparative importance of soil functions may be spatially and temporally dynamic and it is up to the evaluator to define the conditions of evaluation in accordance with the goal of the assessment.

A soil undisturbed by man's activities is considered fertile (Jacks, 1963) if it is able to support the climax population of the plants and animals, including man activities, who lives in dynamic equilibrium on and under the ground. But with very few exceptions, the practice of gathering, which would more than make us our daily bread, is generally gone for most of us! And the man to practice his foster agriculture must disturb the soil. That is why this definition, pure ecology connotation and hard, cannot be the one chosen here. The Soil Science Society of American (SSSA) has somewhat defatted previous definitions of soil fertility, particularly in apparently abandoning, references to nutritional expectations, taste or financial men, sources of so many wars on planet. It defines the fertility of a soil like "The quality of the soil allowing it to supply nutrients in adequate and balanced amounts together to ensure the growth of plants or crops data."

Human activity affects land cover and land use. Land cover is the biophysical state of the earth's surface and immediate subsurface (biota, soil, topography, surface and groundwater, human structures), whereas land use involves the manner 
in which the biophysical attributes of the land are manipulated and the intent underlying that manipulation for which the land is used

\section{MATERIALS AND METHODS}

Study location

The study was conducted on the Aries Corridor and the areas are located on the centralwestern part of the Transylvanian Basin, between Buru Gorges and Mures valley area.

Soils Sampling and processing

Soils sampling was conducted in the period between 2012-2014 and June 2011. In order to determine bulk density (BD), a sample of $5 \mathrm{~cm}$ diameter and $10 \mathrm{~cm}$ length $\left(100 \mathrm{~cm}^{3}\right.$ core volume) was taken from each soil section. In the laboratory, soil samples were air-dried and passed through a $2 \mathrm{~mm}$ sieve to remove gravels and roots for the texture analysis. The distribution of the soil

particle size was analyzed by sieving and using the pipette method. Soil $\mathrm{pH}$ was determined in a $1: 2.5$ soil to water ratio. SOC was determined by wet oxidation with dichromate according to the Walkley-Black method.

\section{RESULTS AND METHODS}

Geology

The Aries Lower Corridor has configuration of a convex arc oriented to north. Compared to the Aries River, this valley has a fairly obvious geomorphological asymmetry, being narrower

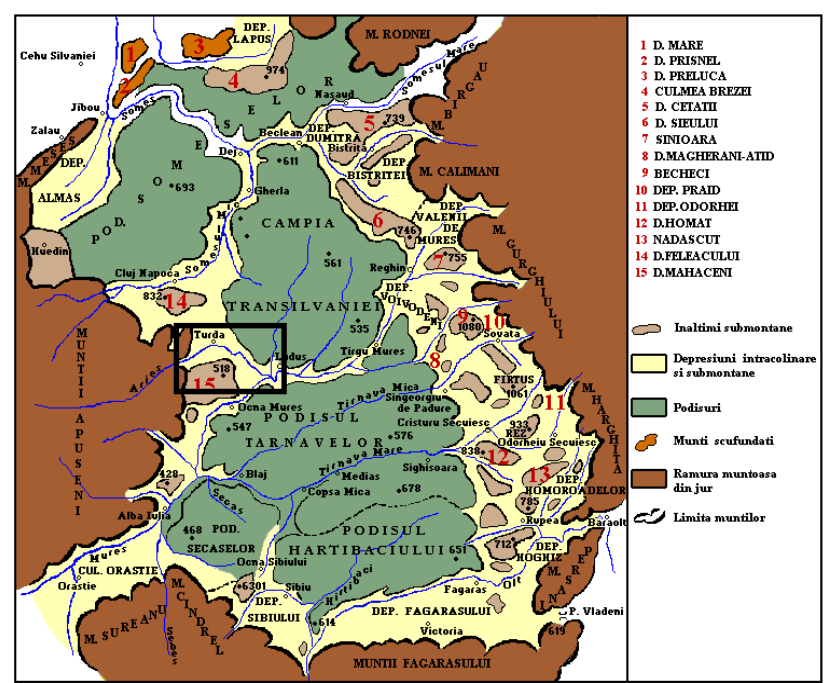

Fig. 1. Location of the Aries Corridor in the Transylvanian Depression and steeper on the eastern side (the cuesta) and wide and a tabular layout on the west side, in the terraces. Asymmetry relief and slope morphology are due to geological strata, with tilting layers in the direction N-NE; resulting in a discordant slope (to left) and other concordant (to right).

In the terms of geological composition there is a relatively simple structure; the entire region is composed by the sedimentary formations of the Badenian, Sarmatian and Quaternary. Only contact with the mountainous area, this valley is closed by Mesozoic magmatic "ofiolitic" rocks.

\section{A. Magmatic formations}

Magmatic „ophiolitic" area is specific in the northern sector of the valley at the contact with the mountainous area. The ophiolitic complex is "lithologicaly, a complex of basic rocks (diabase, basalt and basic pyroclastics, volcanic tuffs and breccias respectively) in association with rhyolites and andesite (Grandabura, 1981). The big difference of hardness or resistance to the destructive action of external agents, of these Miocene igneous and sedimentary rocks (detrital) at the contact to the Transylvanian Plain), explains the pronounced morphological elevation to contact them.

\section{B. Sedimentary formations}

Badenianformations-consist of conglomerates, micro-conglomerates, Tithonia limestone, clay, carbonatic clay, and gypsum. Within the Lower Badenian there is the deep salt deposit located deep in the Turda area.

Sarmatian formations- are distinguished by the highest development in the region, being situated both right and left sides of Aries River. The morphological these geological sedimentary formations contribute to a hilly relief with peaks do not exceed an altitude of $400 \mathrm{~m}$. The Sarmatian deposits are represented mainly by clays and carbonatic clay with intercalations of sands, sometimes poorly cemented sandstone.

Pannonian formations- which appear on a small area, being represented by uncemented rocks (gravel, sand) and poorly consolidated rocks (clays, clay marl etc.).

Quaternary formations- include relatively recent geological formations age in which we can separate the Pleistocene deposits (Quaternary lower) and the Holocene deposits (upper 
Quaternary). The Pleistocene formations appear appears as a continuous strip developed over a width of 5-8 km, on the right side of Aries river as a small patches on the interfluves area, but prominently on the upper terraces levels of the river. In terms of lithology, the Pleistocene deposits are composed mostly of gravels and sands, along with crystalline schist (mica), gneiss, amphibolites, quartzite (rarely crystalline limestone etc.). Holocene deposits are specific to the lower terraces of Aries River (1-5 km wide) and minor flood plain of Aries River and it consist of gravels and sands with similar petrographic characteristics as the Pleistocene deposits.

\section{Relief}

This differential erosion generated at the contact hard rocks (limestone and Mesozoic ophiolites) of Trascău Mountains with the Neogene sedimentary formations of the Transylvanian Depression, the formation of this corridor that looks like a funnel (cone) to the confluence with the Mureş River.

The large valley character of this region is defined by a number of features of the landscape. So, the local relief is characterized by an attenuation of the contact with the cuestas area by the presence of a piedmont glacis train modeled by Aries River and fragmented by small valleys. The big river of this region generated a huge alluvial system relatively flat, protected from flooding, along with an impressive terraces system (6 terraces) situated on the right side.

In the cross section of the valley, from west to east, on the right side of the Aries River are present the classical steps of fluvial relief, such as floodplain, terraces system, well developed and strip interfluves. On the left side of the corridor, the terraces system is only marked by the sixth level (70-75 m), considered to be distorted by the interference of the salt diapir from Turda. What is specific, in the left side of this corridor, there is a direct contact of the floodplain, through a vast glacis, with the cuestas area, located at 180-200 m above the river.

The six levels that make up the system of terraces in the lower Aries Corridor appear as a continuous strip from the Trascău Mountains and river Mures. At the confluence of the river collector Mureș with Arieș River, there is an active area of subsidence, which has influenced the evolution of the river system.

The average altitude of Aries Lower Corridor region decreases gradually from the BuruMoldovenesti Gorges (Trascau Mountains), where the elevation is $560 \mathrm{~m}$ to the confluence with the Mures River, where the altitude is $260 \mathrm{~m}$.

The series of six levels of terraces, beginning with the 3-6 m (t1), 10-12 m (t2), 20-25 (t3), 35-

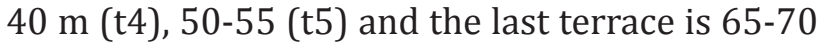
$\mathrm{m}(\mathrm{t} 6)$. The age of the first four levels of the system is considered belonging to the Late Pleistocene and Middle Pleistocene; meantime the last two levels of terrace belong to the Lower Pleistocene (Morariu, Garbacea, 1960). The interfluves patches belong to the Pannonian period.

From the issue of Aries River out of the mountains, through the Buru-Moldovenesti Gorges, to the confluence with the Mures River, the lower terraces represent large alluvial fans, which stretch almost uninterruptedly from west to east.

The floodplain of Aries river with a relative altitude of 3-6 meters is located in this area at the right side of the river, but it is not too large, due to the fact that the stream channel is relatively deep (in this area the main river is keeping some characters of the mountain rivers) and the transition to the first terrace is quite fast. Downstream, at the confluence with Mures River this floodplain, covered by the temporarily marshes, represents an area with the lowest altitude of the Aries Lower Corridor region (260 $\mathrm{m})$, functioning in the same time as the base level of erosion for the whole streams system from the center of Transylvanian Depression.

The smooth character of the fluvial relief from the Lower Corridor Aries region is betrayed by low relief energy and the frequency of the slopes ranging between 4-5․ The floodplain and lower terraces (10-12 m, 20-25 m) have a very low slope of $1-3^{\circ}$, while the slopes with higher values are between $10-15^{\circ}$, being characteristic higher terraces $(50-55 \mathrm{~m}, 65-70 \mathrm{~m})$ and for the scarp of terraces and the slopes bordering the tributary valleys of Aries river. The slopes greater than $20^{\circ}$ appear only on the periphery of the basin, at the contact with the mountainous areas.

\section{Climate}

The climatic differentiation is due to the geographical position, the very close presence of 
mountain ranges with some positional orientations and morphological steps of the relief. Thus, in terms of climate, this corridor is the subject of some geographical general laws, and local laws, which gives some specific characteristics.

The sunshine duration in the Aries Lower Corridor is on average $1928.2 \mathrm{hr} / \mathrm{yr}$ exceeding with almost 170-180 hours the average of the mountainous region. The isotherm of $9^{\circ} \mathrm{C}$, after it entered from the west part of Transylvanian Depression through the Mures valley, makes his presence until the eastern edge of this corridor near to Trascău Mountains. A common climatic phenomenon which appears in the Aries Lower Corridor is the frequent occurrence of the thermal inversions, especially in the late autumn (OctoberNovember) and in winter. This phenomenon is accompanied by a cooling air passage from the mountains. The average annual temperature in situations of thermal inversions is $2-3^{\circ} \mathrm{C}$, much lower than the average normal temperature for this period of the year.

The annual average of temperature in the Lower Corridor is $8,8^{\circ} \mathrm{C}$ Aries, the coldest month of the year is January with $-3,5^{\circ} \mathrm{C}$ (Turda $-3,4$; Câmpia Turzii $-3,8^{\circ} \mathrm{C}$ ), while the highest values of the year is recorded in July $19,7^{\circ} \mathrm{C}$ (Turda $19,3^{\circ} \mathrm{C}$ ).

The atmospheric precipitations (rainfall) are the second important element to characterize any climate. The precipitations (rainfall) annual average does not exceed $500 \mathrm{~mm}$, at Turda, conditioned by the evolution of the foehn air current, much warmer, coming through Trascău Mountains and affecting the entire region studied.

In the years when the cyclonic activity was particularly frequent and very intense the rainfall annual average was about $850-900 \mathrm{~mm}(865 \mathrm{~mm}$ in Turda Turda Plain $862 \mathrm{~mm}$ ), and in the years with the rainfall deficiency this annual average was about $300 \mathrm{~mm}(295,3 \mathrm{~mm}$ - Turda). In the chronological analysis of monthly data, it appears the rainfall regime has a maximum in the summer in June (18,4\% Câmpia Turzii; $17,1 \%$ Turda), and in the winter with a minimum in February $(3,1 \%$ Turda; 2,1\% Turzii). There are, however, significant differences in terms of quantity between monthly values, which exceeding with $80 \mathrm{~mm}$ in the wettest month (June) while the least rainy month (February), the value is less than $15 \mathrm{~mm}$.

The seasonal distributions of rainfall in the summer season are about $41 \%$ of the total of this region. The spring season rainfall amounts are $40-60 \mathrm{~mm}$, which is more abundant than in the winter season, their value exceeding $26 \%$ of the total (27,4\% Câmpia Turzii; 26.9\%- Turda), while in autumn season, due to more pronounced rate regime and weakening anticyclone thermal convection (October-November), the rainfall average decreases with 95-115 $\mathrm{mm}$ from the summer, and the amount representing approximately $20 \%$ of annual rainfall average (18,9\%-Câmpia Turzii; 19,2\%- Turda).

The prevailing wind direction in the region is the north-west $(7,0 \%)$, followed by southeasterly direction $(4,1 \%)$. The lowest frequency is recorded on the dominant opposite directions, such as north-east $(0,9 \%)$. An important role in the of pedoclimatic evolution of this region had foehn phenomenon, a warmer current from Trascău Mountains and who has greatly contribution to the annual average temperature increase and a decrease concerning the rainfall annual average.

In the climatic analysis of this region has taken into account the weight of the calm atmospheric situations. Thus, in this depression corridor the calm atmospheric average is $74,1 \%$. The highest frequency of this calm is recorded in the winter months (December-January), when prevails the stable anticyclone climate, and, the lowest value is observed in May and June, when is recording the most intense climatic instability throughout the year due to Atlantic cyclonic activity.

The negative forms that characterized the landscape of this marginal corridor are less favorable to good urban and industrial ventilation air laden with chemical particulates. The influence of topography is manifested by cold air drainage process, sewerage and accumulation in low places of upper terraces. Cold air stagnation accompanied by increased thermal stability inversion restrains the polluted air ventilation. The cold layers accumulated through this process, during the long winter nights, can become more stable and it cannot be removed either by heating briefly air temperature during the day; it persists for a long period. Often, the upper terraces of the Aries River are covered by air polluted (particulates) under a form of a "bell", and their disappearance in the upper atmosphere it's possible along with the change of weather, accompanied by the emergence of forces turbulent diffusion treatment and the intensity of the wind (Farcas, 1976). 


\section{Hydrogeology}

An important aquifer is the alluvium and terrace sedimentary deposits of the Aries River, reaching the deep of 5-6 m, especially out of the Buru Gorges where it was formed that huge terraced alluvial cone. In the floodplain area the phreatic level is situated approximately at 1,50 $\mathrm{m}$ and then arrived at the upper terraces over $10 \mathrm{~m}$ deep. The terrace sedimentary deposits of Aries River are clogged with a sand-loam material, making possible that aquifers based on the lower terraces brought from north to south an active springs line. In the third terrace area, the specific flow rates observed by drillings may range 6-9 m/s/ $\mathrm{m}$ (Pascal, 1983) and the sediments permeability value is $136-181 \mathrm{~m} /$ day. The piesometric level variation amplitudes are up to $1 \mathrm{~m}$ in the floodplain, $2 \mathrm{~m}$ in the lower terraces and $7 \mathrm{~m}$ in the upper terraces (Pascu, 1983).

The groundwater regime shows a peak in the late of winter and early in the spring along with snowmelt, and the minimum value occurring late in the summer and early autumn (SeptemberOctober), when evaporation is high with a low rainfall average. Following the construction of a width water open pipe (sewer), 45 years ago, for the local heavy industry, the groundwater level within the system of terraces fell by more than 2,0 $\mathrm{m}$ with some negative consequences for the water supply for the local irrigation systems.

\section{Vegetation}

The vegetal cover of the Aries Lower Corridor region shows a transition from mountain area to Transylvanian Plain. On the upper terraces of the river Aries and the interfluvial area appears the forest steppe vegetation, composed of natural grasslands, deciduous forests and the real steppe vegetation islands, including secondary grassland plant associations characteristic of drier climates.

The most common grassland vegetal species in this region are dominated by Festuca rupicola and Agrostis tenuis. The floristic composition of the most important association (Agrostio-Festucetum) is different, which is dominated by: Tripholium pratense, Tripholium repens, Trifolium campestre, Lotus corniculatus, Lolium perenne, Onobrychis vicifolia, Plantago lanceolata, Chrysanthemum Leucanthemum etc.

In the terraces system, the meadows consist mainly of: Carex acutiformis Alopecurus pratensis,
Juncus effusus, Agrostis stolonifera etc. On the dry and drained soils the grasslands are composed by: Festuca ovina duriusculla, Bromus sterillis, Anthoxanthum odoratum, Trifolium pretense, Lorus corniculatus etc.

The forests occupy a much smaller area than those occupied by herbaceous vegetation and it's mainly present only by some islands in the western part of the corridor and intra-zone territories, along watercourses. The dominant tree species for these forests are: Carpinus betulus, Ulmus carpinifolia, Fraxinus excelsior, Quercus petraea etc.

In the Aries Lower Corridor the soil pollution processes are due to the following categories of activities: extractive raw materials (sand quarry), industrial activity (metallurgy, building materials, chemicals products, etc.), farming activities (intensive fertilization of soils, manure resulting from livestock etc.), human activities (landfills, wastewater, etc.).

\section{Soils quality from Aries corridor}

The knowledge of the specific features and characteristics of natural or anthropogenic change of earth as a means of production and partly as a product of human activity has an important role in the rational use of a particular territory and demonstrating that practice to operate large or small farm is the primordial the knowledge and proper organization of the soils cover. According to Romanian Soil Taxonomy System (SRTS 2003) investigated space identified six classes of soil, 10 kinds, approx. 17 subtypes and numerous detailed units. Each detailed units identified in the investigated area were characterized according Soil Assessment Study Methodology (vol. I, II, III), modeled on the 36 UT using the 23 indicators of evaluation, indicators that are important character traits and more significant and measurable precisely, which are usually found in soil studies work (developed after 1987).

The determination tender vegetation factors and environmental conditions of each piece of land for a specific plant or use represent the ability to correctly determine the capability notes and favorability classes (suitability), or more specifically the production capacity of that portion of land $(151,152,172,175,176,178,190,194$, 195).

The evaluation notes as determinations are resulting from a given physical value that had 
a distinct meaning for each crop, the purpose of establishing differentiated favorability and the possibility of obtaining crops with differentiated levels.
The value evaluation notes thus obtained can be used to calculate the average yields per hectare compared to the technological level that it can be achieved at a time $(156,175,210)$.

Tab. 1. Rating marks for main crops and land activities

\begin{tabular}{|c|c|c|c|c|c|c|c|c|c|c|c|}
\hline TEO & Tip subtip & PŞ & $\mathrm{FN}$ & MR & PR & $\mathrm{PN}$ & $\mathrm{CV}$ & $\mathrm{CS}$ & $\mathrm{PC}$ & $\mathrm{VV}$ & $\mathrm{VM}$ \\
\hline 1.01 & AS en & 73 & 65 & 58 & 65 & 52 & 45 & 50 & 51 & 58 & 27 \\
\hline 2.01 & AS en-gz & 60 & 45 & 72 & 72 & 63 & 64 & 80 & 81 & 56 & 29 \\
\hline 3.01 & AS gc & 90 & 81 & 50 & 64 & 65 & 58 & 52 & 52 & 51 & 45 \\
\hline 4.01 & AS mo & 90 & 80 & 90 & 90 & 100 & 100 & 90 & 90 & 90 & 90 \\
\hline 5.01 & AS sc-ac & 73 & 58 & 29 & 29 & 49 & 32 & 32 & 29 & 36 & 32 \\
\hline 6.01 & AS sc-ac & 44 & 31 & 3 & 4 & 5 & 5 & 5 & 4 & 5 & 4 \\
\hline 7.01 & $\mathrm{CZ} \mathrm{ti}$ & 81 & 72 & 90 & 90 & 80 & 90 & 100 & 90 & 100 & 100 \\
\hline 8.01. & $\mathrm{CZ} \mathrm{ti}$ & 90 & 80 & 100 & 100 & 100 & 100 & 100 & 100 & 100 & 100 \\
\hline 9.01 & $\mathrm{CZ} \mathrm{cb}$ & 90 & 81 & 54 & 63 & 70 & 49 & 49 & 49 & 53 & 52 \\
\hline 10.01 & $\mathrm{CZ}$ ar & 81 & 72 & 73 & 73 & 81 & 66 & 66 & 66 & 73 & 73 \\
\hline 11.01 & $\mathrm{CZ} \mathrm{gc}$ & 81 & 80 & 45 & 46 & 65 & 52 & 46 & 41 & 51 & 45 \\
\hline 12.01 & $\mathrm{CZ} \mathrm{gc}$ & 81 & 81 & 43 & 50 & 63 & 44 & 39 & 39 & 50 & 40 \\
\hline 13.01 & $\mathrm{CZ} \mathrm{sc}$ & 73 & 73 & 22 & 28 & 34 & 22 & 19 & 19 & 22 & 20 \\
\hline 14.01 & $\mathrm{CZ}$ ac & 65 & 51 & 10 & 12 & 22 & 13 & 13 & 12 & 13 & 13 \\
\hline 15.01 & $\mathrm{CZ}$ ac & 47 & 41 & 5 & 7 & 12 & 6 & 6 & 5 & 6 & 6 \\
\hline 16.01 & $\mathrm{CZ}$ cb-ac & 65 & 65 & 9 & 10 & 19 & 12 & 10 & 10 & 10 & 8 \\
\hline 17.01 & $\mathrm{FZ} \mathrm{cb}$ & 81 & 72 & 81 & 81 & 90 & 73 & 73 & 73 & 81 & 73 \\
\hline 18.01 & $\mathrm{FZ}$ ar & 64 & 66 & 65 & 72 & 72 & 65 & 65 & 65 & 72 & 65 \\
\hline 19.01 & FZ vs-st & 47 & 32 & 30 & 30 & 38 & 34 & 33 & 28 & 41 & 28 \\
\hline 20.01 & EC ti & 31 & 72 & 73 & 72 & 65 & 65 & 72 & 73 & 72 & 38 \\
\hline 21.01 & EC mo & 90 & 80 & 100 & 100 & 100 & 100 & 100 & 100 & 100 & 100 \\
\hline 22.01 & EC vs & 65 & 58 & 23 & 32 & 36 & 23 & 21 & 21 & 26 & 23 \\
\hline 23.01 & $\mathrm{EC}$ ac & 43 & 34 & 4 & 5 & 6 & 5 & 5 & 5 & 4 & 3 \\
\hline 24.01 & EL ti & 58 & 40 & 41 & 41 & 52 & 52 & 50 & 43 & 58 & 43 \\
\hline 25.01 & EL mo & 64 & 50 & 65 & 72 & 72 & 65 & 65 & 65 & 72 & 65 \\
\hline 26.01 & EL vs & 81 & 65 & 73 & 73 & 81 & 66 & 66 & 66 & 73 & 73 \\
\hline 27.01 & EL st & 59 & 47 & 27 & 36 & 36 & 27 & 23 & 23 & 23 & 15 \\
\hline 28.01 & EL vs-st & 41 & 31 & 20 & 18 & 30 & 27 & 22 & 17 & 25 & 16 \\
\hline 29.01 & VS gc & 73 & 65 & 45 & 46 & 65 & 51 & 46 & 46 & 52 & 46 \\
\hline 30.01 & VS st & 66 & 52 & 32 & 31 & 47 & 37 & 28 & 28 & 31 & 26 \\
\hline 31.01 & VS sc-ac & 39 & 35 & 2 & 3 & 3 & 2 & 2 & 2 & 3 & 2 \\
\hline 32.01 & GS mo & 47 & 38 & 8 & 9 & 14 & 9 & 6 & 7 & 9 & 8 \\
\hline 33.01 & GS sc-ac & 39 & 35 & 2 & 2 & 3 & 2 & 2 & 2 & 2 & 2 \\
\hline 34.01 & SN gc-sc & 35 & 25 & 2 & 3 & 3 & 2 & 2 & 2 & 3 & 2 \\
\hline 35.01 & SN sc & 13 & 6 & 1 & 2 & 3 & 2 & 2 & 1 & 2 & 2 \\
\hline 36.01 & SN bv-st & 28 & 24 & 2 & 3 & 3 & 2 & 2 & 2 & 2 & 2 \\
\hline
\end{tabular}


Tab. 1. Rating marks for main crops and land activities - continued

\begin{tabular}{|c|c|c|c|c|c|c|c|c|c|c|c|c|c|c|c|c|c|c|}
\hline TEO & $\begin{array}{c}\text { Tip } \\
\text { subtip }\end{array}$ & GR & OR & PB & FS & CT & SF & SO & MF & IU & IF & $\mathrm{CN}$ & $\mathrm{LU}$ & TR & LG & $\mathrm{AR}^{*}$ & $\mathrm{AR}^{* *}$ & $\mathrm{AR}^{* * *}$ \\
\hline 1.01 & AS en & 41 & 41 & 52 & 47 & 41 & 51 & 47 & 47 & 45 & 52 & 41 & 58 & 52 & 45 & 51 & 46 & 51 \\
\hline 2.01 & AS en-gz & 36 & 43 & 51 & 45 & 52 & 57 & 36 & 36 & 40 & 63 & 32 & 36 & 36 & 45 & 56 & 45 & 53 \\
\hline 3.01 & AS gc & 65 & 65 & 73 & 65 & 52 & 66 & 58 & 65 & 72 & 62 & 65 & 49 & 58 & 65 & 69 & 64 & 66 \\
\hline 4.01 & AS mo & 90 & 90 & 90 & 100 & 90 & 81 & 100 & 90 & 90 & 81 & 90 & 80 & 80 & 100 & 95 & 91 & 94 \\
\hline 5.01 & AS sc-ac & 52 & 47 & 45 & 52 & 29 & 58 & 52 & 47 & 58 & 37 & 47 & 46 & 33 & 46 & 55 & 48 & 52 \\
\hline 6.01 & AS sc-ac & 10 & 14 & 5 & 14 & 3 & 14 & 4 & 5 & 8 & 4 & 4 & 12 & 4 & 9 & 13 & 9 & 11 \\
\hline 7.01 & $\mathrm{CZ}$ ti & 90 & 90 & 100 & 100 & 90 & 100 & 90 & 90 & 100 & 90 & 90 & 100 & 80 & 100 & 100 & 94 & 98 \\
\hline 8.01. & $\mathrm{CZ}$ ti & 100 & 100 & 100 & 100 & 90 & 100 & 100 & 100 & 90 & 100 & 100 & 100 & 80 & 100 & 100 & 99 & 100 \\
\hline 9.01 & $\mathrm{CZ} \mathrm{cb}$ & 72 & 72 & 72 & 72 & 51 & 65 & 65 & 72 & 63 & 51 & 72 & 72 & 78 & 72 & 72 & 68 & 73 \\
\hline 10.01 & $\mathrm{CZ}$ ar & 81 & 81 & 81 & 81 & 66 & 73 & 81 & 81 & 81 & 66 & 81 & 81 & 65 & 81 & 81 & 78 & 81 \\
\hline 11.01 & $\mathrm{CZ}$ gc & 72 & 72 & 81 & 72 & 58 & 73 & 72 & 72 & 72 & 66 & 72 & 54 & 65 & 81 & 75 & 72 & 74 \\
\hline 12.01 & $\mathrm{CZ}$ gc & 58 & 58 & 65 & 58 & 41 & 58 & 52 & 58 & 50 & 46 & 58 & 43 & 52 & 65 & 60 & 56 & 60 \\
\hline 13.01 & $\mathrm{CZ} \mathrm{sc}$ & 51 & 51 & 50 & 58 & 32 & 58 & 46 & 51 & 45 & 36 & 51 & 36 & 40 & 58 & 55 & 50 & 54 \\
\hline 14.01 & $\mathrm{CZ}$ ac & 36 & 44 & 32 & 51 & 23 & 57 & 36 & 29 & 36 & 23 & 36 & 39 & 20 & 49 & 47 & & 52 \\
\hline 15.01 & $\mathrm{CZ}$ ac & 26 & 28 & 21 & 32 & 12 & 33 & 23 & 18 & 20 & 13 & 23 & 19 & 15 & 31 & 30 & 24 & 27 \\
\hline 16.01 & $\mathrm{CZ} \mathrm{cb}-\mathrm{ac}$ & 32 & 35 & 26 & 40 & 21 & 45 & 26 & 23 & 24 & 23 & 29 & 26 & 23 & 39 & 38 & 31 & 34 \\
\hline 17.01 & $\mathrm{FZ} \mathrm{cb}$ & 81 & 81 & 73 & 73 & 59 & 66 & 73 & 81 & 81 & 66 & 81 & 81 & 65 & 73 & 81 & & 79 \\
\hline 18.01 & $\mathrm{FZ}$ ar & 72 & 72 & 65 & 65 & 47 & 52 & 65 & 72 & 72 & 52 & 72 & 72 & 52 & 65 & 72 & 64 & 70 \\
\hline 19.01 & FZ vs-st & 41 & 37 & 32 & 28 & 13 & 16 & 29 & 37 & 32 & 23 & 29 & 37 & 26 & 20 & 37 & 29 & 34 \\
\hline 20.01 & $\mathrm{EC}$ ti & 58 & 58 & 65 & 58 & 50 & 63 & 58 & 58 & 56 & 72 & 57 & 64 & 65 & 56 & 65 & 59 & 63 \\
\hline 21.01 & EC mo & 100 & 100 & 100 & 100 & 90 & 100 & 100 & 100 & 90 & 100 & 100 & 80 & 100 & 100 & 100 & 99 & 100 \\
\hline 22. & EC vs & 25 & 40 & 39 & 40 & 28 & 35 & 36 & 40 & 38 & 35 & 40 & 30 & 41 & 40 & 41 & 35 & 40 \\
\hline 23.01 & $\mathrm{EC} \mathrm{ac}$ & 9 & 12 & 4 & 10 & 3 & 9 & 3 & 4 & 6 & 3 & 3 & 10 & 5 & 7 & 6 & 7 & 9 \\
\hline 24.01 & EL ti & 47 & 47 & 41 & 35 & 21 & 26 & 37 & 47 & 52 & 36 & 42 & 52 & 29 & 26 & 48 & 38 & 45 \\
\hline 25.01 & EL mo & 65 & 65 & 58 & 58 & 43 & 47 & 56 & 65 & 42 & 52 & 65 & 72 & 47 & 52 & 67 & 57 & 63 \\
\hline 26.01 & EL vs & 73 & 73 & 73 & 73 & 59 & 66 & 73 & 73 & 81 & 66 & 73 & 81 & 58 & 65 & 75 & 70 & 75 \\
\hline 27.01 & EL st & 41 & 37 & 32 & 32 & 16 & 24 & 29 & 32 & 21 & 25 & 24 & 28 & 33 & 28 & 36 & 30 & 33 \\
\hline 28.01 & EL vs-st & 41 & 37 & 25 & 24 & 10 & 11 & 25 & 37 & 37 & 21 & 26 & 41 & 25 & 17 & 38 & 26 & 34 \\
\hline 29.01 & VS gc & 66 & 52 & 58 & 52 & 41 & 58 & 53 & 52 & 58 & 47 & 52 & 46 & 55 & 58 & 60 & 54 & 57 \\
\hline 30.01 & VS st & 47 & 42 & 37 & 37 & 23 & 28 & 37 & 42 & 41 & 38 & 33 & 47 & 43 & 28 & 43 & 37 & 42 \\
\hline 31.01 & VS sc-ac & 9 & 12 & 4 & 12 & 3 & 10 & 4 & 4 & 8 & 3 & 4 & 9 & 3 & 8 & 11 & 7 & 9 \\
\hline 32.01 & GS mo & 24 & 19 & 22 & 22 & 13 & 22 & 20 & 19 & 21 & 22 & 19 & 13 & 26 & 17 & 23 & 20 & 22 \\
\hline 33.01 & GS sc-ac & 8 & 12 & 4 & 14 & 3 & 12 & 4 & 4 & 7 & 3 & 4 & 8 & 3 & 9 & 12 & 8 & 9 \\
\hline 34.01 & SN gc-sc & 8 & 11 & 3 & 11 & 2 & 9 & 3 & 4 & 5 & 2 & 3 & 10 & 3 & 7 & 10 & 6 & 8 \\
\hline 35.01 & SN sc & 3 & 3 & 3 & 3 & 2 & 2 & 3 & 3 & 2 & 2 & 3 & 2 & 2 & 3 & 3 & 3 & 3 \\
\hline 36.01 & SN bv-st & 6 & 8 & 2 & 7 & 2 & 5 & 2 & 3 & 4 & 2 & 2 & 5 & 3 & 5 & 7 & 4 & 5 \\
\hline
\end{tabular}




\section{CONCLUSIONS}

The evaluation notes obtained along with that study highlighted the following issues relating to land quality, suitability in terms of determining the most appropriate uses, determine suitability for certain crops, determining production capacity in $\mathrm{kg} / \mathrm{ha}$. Thus in the space investigated under evaluation marks were established following percentages of the agricultural area, in terms of very suitable areas: $23,3 \%$ pastures, vineyards $18,9 \% 21 \%$ arable, orchard $10,1 \%$, and in terms very favorable areas by meeting the following situation: sunflower $21.48 \% \quad 21.15 \%$ hemp, wheat $18.75 \%, 18.75 \%$ barley, pea beans $18,75 \%$, $18.53 \%$ alfalfa, corn, $13.62 \%, 13.22 \%$ sunflower, soybean, $13.22 \%, 9.08 \%$ potato, sugar beet, $9.08 \%$.

The process of land evaluation has showed a number of limiting factors acting on the productive capacity of agricultural land in the area investigated, such as coarse and fine texture $50.7 \%$ $10.2 \% 28.7 \%$ low humus reserve, excess moisture and groundwater rainwater $30.3 \% 26.8 \%$ 13.6\% small part, stressed $84.4 \%$ compaction degree.

In this case, the knowledge of natural conditions and ecological potential of land for major crops is a defining element in establishing production capacity of soils from Aries Corridor and also to express the pedological value as evaluation notes. One of the main parameter estimation of future action or movement is the value of land and economic.

\section{REFERENCES}

1. Anastasescu I (1976). Cercetări privind schimbările morfo-fizice-chimice, produse sub influența irigațiilor în solurile din Câmpia de Vest, Teză de doctorat, Institutul Agronomic Timișoara.

2. Badea L, Gâștescu P, Velcea V, Bogdan O, Donisă I. Dragomirescu S, Florea N, Niculescu G., Cucu-Popova A, Rusu A., Sencu V (1983). Geografia României (I Geografia fizică), Ed. Academiei Române, București.

3. Baghinschi V (1979). Funcțiile de producție şi aplicaţiile lor în agricultură, Ed. Ceres, București, 1979,

4. Blaga G, Rusu I, Udrescu S, Vasile D (1979). Pedologie, Ed. Didactică şi Pedagogică. R. A., București.

5. Canarache A, Şerbănescu I, Teaci D, Savapol L (1967). Îndrumător pentru studiul solului pe teren și în laborator, Ed. Agrosilvică, București.

6. Doniță N (1963). Elemente pentru interpretarea zonalității vegetației în România, Bot. Hort., Bucurestiensis.

7. Eliade G, Ghinea L, Ştefanic G (1983). Bazele biologice ale fertilității solului, Ed. Ceres, București.

8. Florea N., Untaru G, Berbecel O, Teaci D, Tudor A, Răuță C, Canarache A (1989), Microzonarea pedoclimatică a teritoriului României, Analele I.C.P.A. Bucureşti, vol. XLIX.

9. Hălmăgeanu V (1977). Aspecte privind aplicarea metodei de bonitare pentru optimizarea repartiției sarcinilor de producție, vol XLII.

10. Teaci D, Șerbănescu I (1954). Cercetarea și cartarea solului, Ed. Agrosilvică București.

11. Teaci D (1966). Studii și cercetări privind bonitarea terenurilor agricole, Autoreferat asupra lucrării de doctorat, I.A.N.B. București.

12. Teaci D (1970). Bonitarea terenurilor agricole, Ed. Ceres București. 